\title{
Ulrich Thielemann: Wettbewerb als Gerechtigkeitskonzept, Kritik des Neoliberalismus
}

Metropolis-Verlag, Marburg, 2010

\author{
Juergen G. Backhaus
}

Published online: 25 December 2011

(C) Springer Science+Business Media, LLC 2011

Who is or was Ludwig Wittgenstein? The author of Tractatus Logico-Philosophicus, Frankfurt, Suhrkamp 1998 (p. 490).

In his book entitled Competition as a Principle of Justice, Ulrich Thielemann, a student of the eminent Swiss business economist Peter Ulrich the central message of this book is that competition needs to be restrained because of results that are ethically unacceptable. Yet, it is a matter of defining the desired result before the process of competition can be unleaded. This will result in the proposition of results and the process of how to achieve them.

The book is widely researched-it boards a list of references of some forty pages; unfortunately, Thielemann ignors Yuichi Shionoya's the Ethics of competition . ${ }^{1}$

Reading this book would benefit the author and spare the reader an annoying detour.

${ }^{1}$ European Journal of Law and Economics, vol. 2, no. 1, pp. 5-19.

J. G. Backhaus ( $\square)$

Krupp Chair in Public Finance and Fiscal Sociology, University of Erfurt, Nordhäuser Strasse 63, 99089 Erfurt, Germany

e-mail: juergen.backhaus@uni-erfurt.de 